\title{
Application of Stabilized Nanoparticles for In Situ Remediation of Metal-Contaminated Soil and Groundwater: a Critical Review
}

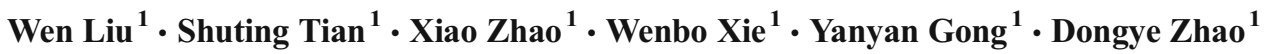

Published online: 23 September 2015

(C) Springer International Publishing AG 2015

\begin{abstract}
Remediation of soil and groundwater contaminated with toxic metals has been a major environmental challenge for decades. Yet, cost-effective and sustainable in situ remediation technologies remain lacking. Over the last 15 years or so, an innovative in situ remediation strategy has shown promising by means of stabilized nanoparticles. Stabilized nanoparticles are prepared using novel stabilizers that facilitate the deliverability and transport of nanoparticles in the subsurface. This study reviews synthesis and characterization of some model stabilized nanoparticles and their application for remediation of metal-contaminated soil and water. Fate and transport of these stabilized nanoparticles in groundwater and soil are also examined. Lastly, this review identifies the key knowledge gaps such as lack of field data pertaining to the long-term effectiveness of the immobilized metals and impacts of the delivered nanoparticles on the biogeochemical conditions in the subsurface. The information may facilitate further development of this promising remediation technology.
\end{abstract}

Keywords Stabilized nanoparticle · Metal - Immobilization · Adsorption · Soil · Groundwater

This article is part of the Topical Collection on Water Pollution

Wen Liu, Shuting Tian and Xiao Zhao contributed equally to this work.

Dongye Zhao

ZHAODON@auburn.edu

1 Department of Civil Engineering, Environmental Engineering Program, Auburn University, Auburn, AL 36849, USA

\author{
Abbreviations \\ AAM Acrylamide \\ $\mathrm{C}-\mathrm{Fe}^{0} \quad$ Carbon-supported nanoscale zero-valent iron particles \\ CMC Carboxymethyl cellulose \\ D.S. Degree of substitution \\ DBD Dielectric barrier discharge \\ DLS Dynamic light scattering \\ DOE Department of Energy \\ FTIR Fourier transform infrared spectroscopy \\ M.W. Molecular weight \\ MNPs Iron oxide magnetic nanoparticles \\ MTD Maximum travel distance \\ NOM Natural organic matter \\ nZVI Nanoscale zero-valent iron \\ PAA Polyacrylate \\ PAAM Polyacrylamide \\ PAP Polyaspartate \\ PBET Physiologically based extraction test \\ PRBs Permeable reactive barriers \\ PSS Polystyrene sulfonate \\ PV Pore volumes \\ SDBS Sodium dodecyl benzene sulfonate \\ TCLP Toxicity characteristic leaching procedure \\ TEM Transmission electron microscopy \\ WET Waste extraction test \\ $\mathrm{wt} \% \quad$ Weight percent \\ XPS X-ray photoelectron spectroscopy \\ XRD X-ray diffraction \\ ZVI Zero-valent iron
}

\section{Introduction}

Remediation of soil and groundwater contaminated with toxic metals has been a major environmental challenge for decades. 
Among the top-listed metals are lead $(\mathrm{Pb})$, cadmium $(\mathrm{Cd})$, mercury $(\mathrm{Hg})$, chromium $(\mathrm{Cr})$, arsenic $(\mathrm{As})$, and a host of the radionuclides such as uranium (U) and technetium (Tc). Yet, cost-effective and sustainable in situ remediation technologies remain lacking.

In general, these important metals can be classified as the following: (1) heavy metal cations, such as $\mathrm{Pb}, \mathrm{Cd}$, and $\mathrm{Hg}$; (2) oxyanions such as arsenate and chromate; and (3) radionuclides such as uranium and technetium. Cationic heavy metals are the most commonly detected contaminants in soil and groundwater, which can cause acute or chronic toxic effects on human and environmental health $[1,2]$. In addition to potent toxicity, these heavy metals are persistent and can bio-accumulate in the environment $[3,4]$. The main sources of these contaminants are from anthropogenic activities such as mining and electrical and electronics manufacturing [5]. Metal cations are often strong. Lewis acids can be removed from water through adsorption and precipitation [6-8]. Metal or metalloid oxyanions are also rather common contaminants, many of which are strong ligands such as arsenate, chromate, and selenate. For example, As is a highly toxic metalloid and has been detected in soil and groundwater as arsenite $\mathrm{As}(\mathrm{III})$ and arsenate $\mathrm{As}(\mathrm{V})[9,10]$. $\mathrm{Cr}(\mathrm{VI})$ is considered to be one of the most common metal contaminants in soil and water due to widespread industrial applications [11]. These oxyanions can be immobilized through surface complexation and precipitation. Radionuclides have received growing attention in recent years with increasing nuclear energy development. Processing of nuclear fuels and mining activities have resulted in sprawling radionuclides contamination around the related sites. Radionuclides were detected in groundwater in $66 \%$ of US Department of Energy (DOE) facilities [12]. $\mathrm{U}(\mathrm{VI})$ and $\mathrm{Tc}(\mathrm{VII})$ are the most commonly detected radionuclides in soil and groundwater [13].

It is noteworthy that many of the metals or radionuclides are redox-active, i.e., their oxidation states may vary according to the redox conditions. The most common redox-active pairs include $\mathrm{As}(\mathrm{V})-\mathrm{As}(\mathrm{III}), \mathrm{Cr}(\mathrm{VI})-\mathrm{Cr}(\mathrm{III}), \mathrm{Se}(\mathrm{VI})-\mathrm{Se}(\mathrm{IV})$, $\mathrm{U}(\mathrm{VI})-\mathrm{U}(\mathrm{IV})$, and Tc(VII)-Tc(IV). Interestingly, the chemicals of different oxidation states may show very different solubility/mobility and toxicity. For instances, As(III), $\mathrm{Cr}(\mathrm{VI})$, $\mathrm{Se}(\mathrm{VI}), \mathrm{U}(\mathrm{VI})$, and $\mathrm{Tc}(\mathrm{VII})$ are considered more mobile and toxic than the respective counterparts.

Nanotechnology has evolved into a promising and potentially cost-effective cleanup strategy for in situ remediation of metal-contaminated sites over the last decade or so [14]. Properly stabilized nanoparticles can be delivered directly into the contaminated aquifer to reach contaminants that are not reachable by conventional technologies, such as contaminants located in deep aquifers or those under surface obstacles [15]. Müller and Nowack estimated that the in situ injection technology for treating chlorinated solvents can potentially reduce remediation cost by up to $90 \%$ compared to the pump-and-treat technology [16].

Nanoparticles prepared without a stabilizer tend to aggregate rapidly into micron- or millimeter-scale clusters, thereby losing their soil deliverability and reactivity $[17 \bullet \bullet, 18]$. To prevent particle aggregation and improve soil deliverability, various particle stabilizing techniques have been developed over the last decade or so. For instance, low-cost and "green" polysaccharides (e.g., starch and carboxymethyl cellulose $(\mathrm{CMC})$ ) have been found highly effective in stabilizing various nanoparticles such as zero-valent iron (ZVI), iron sulfide, magnetite, iron phosphate, Fe-Mn oxides, and $\mathrm{MnO}_{2}[4,10,14,15$, 18-20, 21•, 22•, 23]. The stabilizers can facilitate controlling the size, reactivity, soil delivery, and transport of nanoparticles.

When used for remediation of heavy metal-contaminated soil and groundwater, stabilized nanoparticles offer some unprecedented advantages over traditional aggregated particles, including (a) they can be delivered and dispersed in soil and (b) offer strong affinity or reactivity and high sorption capacity toward the target metals. For examples, stabilized ZVI nanoparticles can facilitate in situ reductive immobilization of $\mathrm{U}(\mathrm{VI}), \mathrm{Tc}(\mathrm{VII}), \operatorname{Re}(\mathrm{VII})$, and $\mathrm{Cr}(\mathrm{VI})$ in soil and groundwater.

This review paper aimed to provide an updated account of the application of stabilized nanoparticles for immobilization of heavy metals and radionuclides in soil and groundwater. The specific objectives were to (a) overview preparation and characterization of representative stabilized nanoparticles designed specifically for heavy metals removal or immobilization, (b) summarize treatment effectiveness of stabilized nanoparticles, (c) elucidate underlying mechanisms, (d) examine fate and transport of stabilized nanoparticles that are delivered in soil and groundwater, and (e) identify knowledge gaps and future research needs.

\section{Synthesis, Characterization, and Application of Stabilized Nanoparticles}

For nanoparticle stabilization, two strategies are commonly used (1) pre-agglomeration stabilization, i.e., stabilizer is added before the formation of aggregates or nanoparticles, and (2) post-agglomeration stabilization, i.e., the stabilizer is added after the nanoparticle agglomerates in order to disperse the nanoparticles through surface modification [14]. In general, pre-agglomeration stabilization forms smaller nanoparticles as the stabilizer molecules interact with the nanoparticles during their formation and growth period, while for postagglomeration stabilization, more energy is required to break down the formed aggregates [17••]. Low-cost, food-grade polysaccharides (e.g., starches, celluloses, and chitosan) and their derivatives have been found the most effective and "green" stabilizers to yield nanoparticles potentially suitable 
for the in situ injection uses $[4,10,14,15,18-20,21 \bullet, 22 \bullet, 23]$. These stabilizers are either commercially available or can be easily obtained by modifying natural polysaccharides. Generally, a stabilizer can enhance dispersion of nanoparticles through: (1) electrostatic stabilization (adsorption of charged stabilizer molecules onto the core nanoparticles, and then create an electrical double layer, causing the Coulombic repulsion between the stabilizer-capped particles), (2) steric stabilization (coating the nanoparticles with sterically bulky stabilizers such as polymers impedes particle attractions through the osmotic repulsive force), and (3) electrosteric stabilization (through combined electrostatic and steric interactions). The synthesis, morphology, property, and metal removal effectiveness of model stabilized nanoparticles (ZVI, FeS, magnetite, iron phosphate, and Fe-Mn oxides) are presented in the following sections.

\section{Stabilized ZVI Nanoparticles}

ZVI is the most studied nanoparticles. The earliest studies on ZVI particles can be dated back to 1953 by Schlesinger et al. [24], and borohydride was applied as the key reducing agent to produce fine iron powder. Yet, detailed studies on the chemistry were not reported until 1990 by Corrias et al. [25] and then 1995 by Glavee et al. [26], who were the first to determine the size of synthesized powder and started to use the term "nanoscale Fe powder." Although granular ZVI had been used in permeable reactive barriers (PRBs) for decades, the environmental application of nanoscale ZVI (nZVI) was not conceived until 1997 by Wang and Zhang [27]. Taking advantage of the high mobility and much greater specific surface area and reactivity of nanoparticles, ZVI nanoparticles hold the potential to be more effectively delivered to contaminant source zones, promoting rapid in situ degradation or reductive immobilization of various priority contaminants. Conventionally, ZVI nanoparticles are synthesized by reducing $\mathrm{Fe}(\mathrm{II}) / \mathrm{Fe}$ (III) by $\mathrm{NaBH}_{4}$ in aqueous solutions at ambient temperature and under anoxic conditions, as depicted by Eqs. 1 and 2 [27]:

$$
\begin{aligned}
& \mathrm{Fe}\left(\mathrm{H}_{2} \mathrm{O}\right)_{6}^{3+}+3 \mathrm{BH}_{4}^{-}+3 \mathrm{H}_{2} \mathrm{O} \rightarrow \mathrm{Fe}^{0}+3 \mathrm{~B}(\mathrm{OH})_{3}^{+} \\
& +10.5 \mathrm{H}_{2} \\
& \mathrm{Fe}^{2+}+\mathrm{BH}_{4}^{-}+4 \mathrm{H}_{2} \mathrm{O} \rightarrow \mathrm{Fe}^{0}+\mathrm{B}(\mathrm{OH})_{4}^{-}+2 \mathrm{H}_{2}
\end{aligned}
$$

However, because of the high surface energy and strong van der Waals and magnetic interactions, ZVI nanoparticles are very labile both physically and chemically. In the absence of an effective stabilizer, ZVI nanoparticles agglomerate rapidly (in a few minutes) into micron-scale or larger aggregates, thereby losing their mobility and reactivity $[18,28]$. To prevent ZVI agglomeration, modification of ZVI with various stabilizers, support materials, or dispersants has been investigated intensively. Hoch et al. [29] synthesized a kind of carbon-supported nanoscale zero-valent iron particles (C$\mathrm{Fe}^{0}$ ) and then modified with $\mathrm{CMC}$ and polyacrylate (PAA) and found the modified particles can effectively remove $\mathrm{Cr}(\mathrm{VI})$ and are transportable through porous media.

To improve soil deliverability, various "pre-aggregation" stabilization methods were developed later. For example, Schrick et al. [28] employed carbon nanoparticles and poly(acrylic acid) as "delivery vehicles" before nZVI formation, resulting in improved soil mobility of the nanoparticle. He and Zhao $[14,18]$ synthesized highly soil-dispersible ZVI nanoparticles using food-grade starch and CMC as stabilizers. CMC, a modified polysaccharide with a $\mathrm{p} K_{\mathrm{a}}$ value of 4.3 [19], can effectively stabilize various metal or semiconductive nanoparticles through concurrent steric and electrostatic stabilization mechanisms [19, 29]. At an Fe concentration of $0.1 \mathrm{~g} /$ $\mathrm{L}$ and with $0.2 \%(w / w)$ of CMC (M.W. $=90,000)$, highly stable discrete ZVI nanoparticles were obtained with a hydrodynamic diameter of $18.6 \mathrm{~nm}$ (Fig. 1a) [14]. Increasing the $\mathrm{CMC} / \mathrm{Fe}^{2+}$ molar ratio resulted in smaller nanoparticles (Fig. 1). In addition, smaller nanoparticles were obtained by CMC of a greater M.W. or higher D.S. (degree of substitution) and lower synthesizing temperature. Mechanistically, CMC stabilizes the nanoparticles through accelerating initial nucleation of $\mathrm{Fe}$ atoms, thereby promoting more effective seed particles during the nanoparticle formation and growth. Subsequently, negatively charged CMC molecules are attached on the ZVI nanoparticles, thus preventing the nanoparticles from agglomeration through electrosteric stabilization [14].

Because of the strong reducing power and unprecedented soil deliverability of CMC-stabilized ZVI, the nanoparticles have been widely studied for remediation of contaminated soil and water. Xu and Zhao [20] proposed a reductive immobilization technology using CMC-stabilized ZVI for in situ reductive immobilization of $\mathrm{Cr}(\mathrm{VI})$ in soil and groundwater. Their bench-scale experimental results indicated that $1 \mathrm{~g}$ of stabilized ZVI can reduce and remove $252 \mathrm{mg} \mathrm{Cr}(\mathrm{VI})$ from water, which is 20 times greater than that observed by Ponder et al. [30]. When a $\mathrm{Cr}(\mathrm{VI})$ laden soil was amended with $0.08 \mathrm{~g} / \mathrm{L}$ of the ZVI nanoparticles, the leachability of $\mathrm{Cr}$ was reduced by nearly $50 \%$. Column experiments indicated that the stabilized nanoparticles were highly deliverable through the soil. When the soil column was treated with 5.7 bed volumes of $0.06 \mathrm{~g} / \mathrm{L}$ of the nanoparticles, all leachable $\mathrm{Cr}(\mathrm{VI})$ was transferred to $\mathrm{Cr}(\mathrm{III})$. In addition, the ZVI treatment reduced the toxicity characteristic leaching procedure (TCLP)-based leachability by $90 \%$. Wang et al. [31] also reported that CMC-stabilized ZVI nanoparticles displayed much less aggregation and greater $\mathrm{Cr}(\mathrm{VI})$ reducing power than non-stabilized counterparts.

Stabilized ZVI is also effective for the reductive immobilization of radionuclides. Liu et al. [32] found that $>96 \%$ of $10 \mathrm{mg} / \mathrm{L}$ perrhenate $\left(\mathrm{ReO}_{4}{ }^{-}\right)$(a surrogate for pertechnetate) was reduced within $8 \mathrm{~h}$ by $560 \mathrm{mg} / \mathrm{L}$ starch-stabilized nZVI 
Fig. 1 TEM images of CMCstabilized ZVI nanoparticles synthesized with different CMC concentrations: a freshly prepared at $0.1 \mathrm{~g} / \mathrm{L} \mathrm{Fe}$ and in the presence of $0.2 \%(w / w) \mathrm{CMC}$ or at $\mathrm{CMC} /$ $\mathrm{Fe}=0.0124$ and $\mathbf{b}$ in the presence of $0.1 \%(w / w) \mathrm{CMC}$ or at $\mathrm{CMC} /$ $\mathrm{Fe}=0.0062[14]$
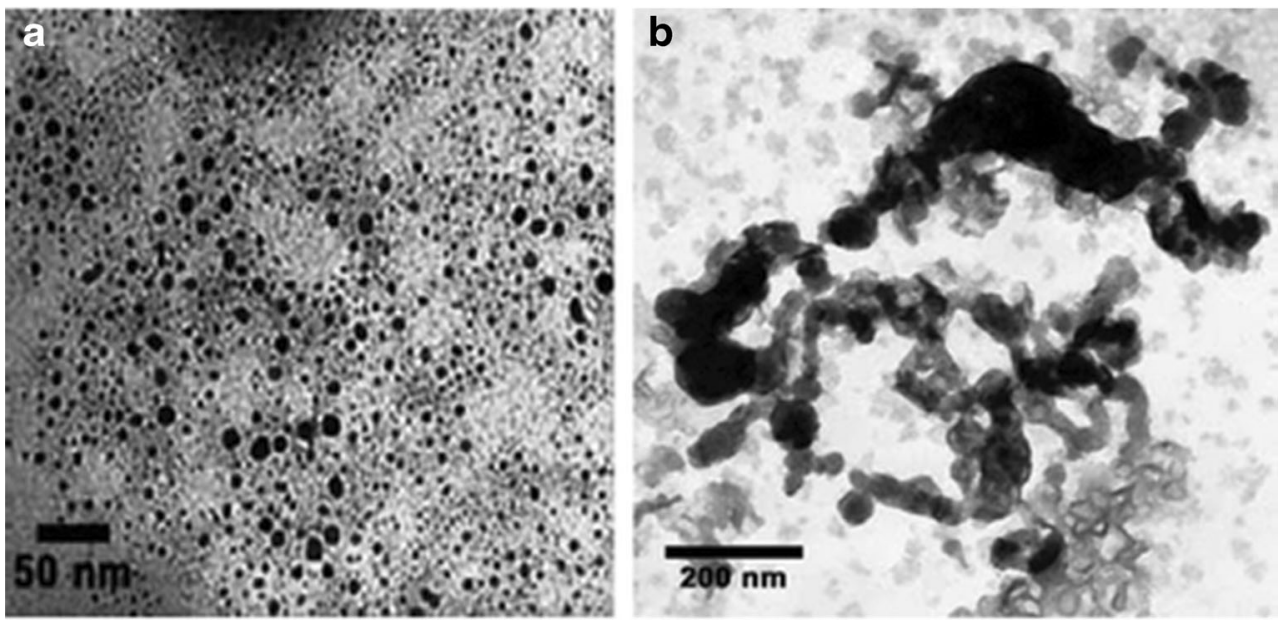

at $\mathrm{pH}$ 6.9. Their column test results confirmed that the stabilized nanoparticles were transportable through a sandy soil, and the water leachable perrhenate from the soil was reduced by $57 \%$, and nearly all eluted $\mathrm{Re}$ was in the form of $\mathrm{ReO}_{2}(\mathrm{~s})$ when the soil was treated with 14 pore volumes (PV) of $560 \mathrm{mg} / \mathrm{L}$ (as Fe) ZVI suspension at $\mathrm{pH}$ 7.2. For U(VI), a number of studies have observed effectiveness of conventional ZVI particles (either powder or non-stabilized synthetic aggregates) for reduction of U(VI) to U(IV) [33-36], yet there has been no report on in situ remediation using stabilized ZVI.

While the CMC coating induces a highly negative surface potential on ZVI particles, the coating of the neutral starch molecules gives nearly neutral particle surface [37]. Starch stabilization was also found to enhance ZVI's ability for arsenic removal from aqueous solutions [38]. Kanel et al. [39] also reported that polyoxyethylene sorbitan monolaurate-stabilized ZVI nanoparticles can effectively remove As(III) from water.

Overall, stabilized ZVI nanoparticles are most suitable for immobilization of toxic metals when the reducing power of the particles is utilized. Given that many important metal contaminants are redox-active such as $\mathrm{Cr}(\mathrm{VI})$, $\mathrm{U}(\mathrm{VI}), \mathrm{Tc}(\mathrm{VII})$, and $\mathrm{V}(\mathrm{V})$, the nanoparticles can reduce the more mobile/soluble metal species into their less mobile species, thereby providing a powerful alternative. However, care should be taken when reduction transformation is not desired, e.g., $\mathrm{As}(\mathrm{V})$ to $\mathrm{As}(\mathrm{III})$. If only adsorptive removal is needed (i.e., for non-redox-active metals), then other cheaper adsorbents such as iron oxides should be considered.

\section{Stabilized FeS Nanoparticles}

Sulfur-containing minerals are known to offer strong affinity for $\mathrm{Hg}\left(K_{\mathrm{sp}}\right.$ of $\left.\mathrm{HgS}=2 \times 10^{-53}\right)$ [40]. Of the common S-containing minerals such as pyrite $\left(\mathrm{FeS}_{2}\right)$, greigite $\left(\mathrm{Fe}_{3} \mathrm{~S}_{4}\right)$, amorphous $\mathrm{FeS}$, and mackinawite (FeS) [41], iron sulfide $(\mathrm{FeS})$ has drawn of the greatest attention due to its high $\mathrm{Hg}^{2+}$ sorption capacity, ubiquitous presence, and long-term stability in anoxic sediments [3]. However, non-stabilized $\mathrm{FeS}$ particles tend to aggregate and thus are not deliverable into contaminated soil/sediment.

To facilitate in situ remediation uses, various methods have been investigated for preparing FeS nanoparticles with controlled particle morphology and size distribution in recent years [42-46], including reverse micelle [42], high-energy mechanical milling [43], polymer-stabilized wet-chemical synthesis [44], poly(amidoamine) dendrimer-stabilization [45], and sulfate-reducing bacteria-assisted production [46]. Xiong et al. developed a "green" technique for preparing a new class of stabilized FeS nanoparticles by applying low concentration of $\mathrm{CMC}$ as a stabilizer during particle synthesis [4]. Specifically, a CMC (M.W. $=90,000)$ solution and a $\mathrm{FeSO}_{4}$ solution are mixed to form a solution of $\mathrm{Fe}^{2+}-\mathrm{CMC}$ complexes under anaerobic conditions. Then, a $\mathrm{Na}_{2} \mathrm{~S}$ solution is added to form the desired FeS nanoparticles. The molar ratio of CMC-to-Fe can be varied to yield nanoparticles of various sizes.

In Gong's study [47•], TEM images indicated that nonstabilized FeS formed aggregates rapidly due to the van der Waals's force and precipitated within $5 \mathrm{~min}$, while CMCstabilized $\mathrm{FeS}$ nanoparticles remained fully dispersed in water with a mean particle size of $34.3 \pm 8.3 \mathrm{~nm}$. The stabilization of the particles is facilitated through adsorption of CMC molecules onto the surface of the particles, resulting in a highly negative zeta potential between -43 and $-68 \mathrm{mV}$ over the $\mathrm{pH}$ range of 5 to $11[47 \bullet]$. Therefore, the CMC coating induces strong inter-particle electrostatic and steric repulsions that overweigh the attractive forces, thereby preventing aggregation of the nanoparticles.

$\mathrm{FeS}$ nanoparticles were found highly effective for removal/immobilization of $\mathrm{Hg}(\mathrm{II})$ in water, sediment, and soil $[4,47 \cdot, 48]$. 
$\mathrm{Hg}$ can be immobilized by FeS through concurrent surface complexation, structural incorporation, and precipitation as a discrete sulfide phase $(\mathrm{HgS}(\mathrm{s}))[3,4]$ :

$$
\begin{aligned}
& \mathrm{FeS}(\mathrm{s})+\mathrm{Hg}^{2+} \rightarrow \mathrm{FeS}^{-\mathrm{Hg}^{2+}} \text { (Surface complexation) (3) } \\
& \mathrm{FeS}(\mathrm{s})+x \mathrm{Hg}^{2+} \rightarrow\left[\mathrm{Fe}_{1-x} \mathrm{Hg}_{x}\right] \mathrm{S}(\mathrm{s})+x \mathrm{Fe}^{2+}(x<1) \\
& \text { (Hg inclusion into } \mathrm{FeS} \text { ) }
\end{aligned}
$$$$
\mathrm{FeS}(\mathrm{s})+\mathrm{Hg}^{2+} \rightarrow \mathrm{HgS}+\mathrm{Fe}^{2+} \text { (Chemical precipitation) }
$$

Xiong et al. [4] found that when a Hg-laden sediment was treated with CMC-stabilized FeS at a FeS-to-Hg molar ratio of 26.5, the water-leachable $\mathrm{Hg}$ concentration was reduced by $97 \%$ and the TCLP leachability of Hg by $99 \%$. Gong et al. [47•] found that the $\mathrm{Hg}(\mathrm{II})$ adsorption capacity increased by $20 \%$ as the CMC-to-FeS molar ratio increased from 0 (nonstabilized) to 0.0006 . Moreover, they found that the primary removal mechanisms include surface inner sphere complexation, precipitation (formation of cinnabar and metacinnabar), and ion exchange (formation of $\mathrm{Hg}_{0.89} \mathrm{Fe}_{0.11} \mathrm{~S}$ ). Enhanced $\mathrm{Cr}(\mathrm{VI})$ removal by $\mathrm{CMC}$-stabilized FeS nanoparticles was also reported [49]. Others reported a ternary magnetic composite of poly(acrylamide)-stabilized $\mathrm{FeS} / \mathrm{Fe}_{3} \mathrm{O}_{4}$ (PAAM-FeS/ $\mathrm{Fe}_{3} \mathrm{O}_{4}$ ), which was synthesized by co-precipitation of $\mathrm{FeS} /$ $\mathrm{Fe}_{3} \mathrm{O}_{4}$ in the presence of acrylamide (AAM) and subsequent dielectric barrier discharge (DBD) plasma-induced polymerization of AAM on the composite surface [50]. The modified material not only showed improved dispersion properties but also good efficiency for U(VI) removal. It was indicated that both $\mathrm{FeS}$ and amide groups on $\mathrm{PAAM}-\mathrm{FeS} / \mathrm{Fe}_{3} \mathrm{O}_{4}$ surfaces have strong affinities for $\mathrm{U}(\mathrm{VI})$, and $\mathrm{FeS}$ can effectively reduce $\mathrm{U}(\mathrm{VI})$ to $\mathrm{U}(\mathrm{IV})$ (in the form of $\mathrm{UO}_{2}$ ) [50].

Adsorptive removal of some other metal cations, like $\mathrm{Pb}(\mathrm{II}), \mathrm{Cd}(\mathrm{II})$, and $\mathrm{Cu}(\mathrm{II})$, by non-stabilized $\mathrm{FeS}$ has been studied for years [41, 51-53]. Similar to $\mathrm{Hg}(\mathrm{II})$, these metals can form sulfide phases that are less soluble than $\mathrm{FeS}$ and can be adsorbed by $\mathrm{FeS}$ strongly via surface complexation [41]. However, little information is available on the effectiveness of stabilized FeS nanoparticles. Moreover, while FeS has been recognized to be an effective reducing agent due to $\mathrm{Fe}^{2+}$ and $\mathrm{S}^{2-}$ ions [54-56], little is known on the effects of FeS on redox-active metals such as $\mathrm{U}(\mathrm{VI})$ and $\mathrm{Tc}(\mathrm{VII})$ and on the effects of stabilizers on the reactivity of the nanoparticles.

\section{Stabilized Magnetite Nanoparticles}

Nanoscale iron oxides have attracted growing interest in water treatment and environmental remediation in recent years due to their high adsorptive capacities to some important water contaminants (e.g., As) [57-60]. Magnetite $\left(\mathrm{Fe}_{3} \mathrm{O}_{4}\right)$ is a ubiquitous magnetic iron oxide existing in the lithosphere, pedosphere, and biosphere [61]. The co-precipitation method by Anderson [62] has been the most widely employed approach for preparing magnetite particles for its straightforward procedure and the convenience for controlling size and shape. Typically, this method starts with a solution containing both $\mathrm{Fe}^{3+}$ and $\mathrm{Fe}^{2+}$ at a molar ratio of 2:1. Upon addition of a base (e.g., $\mathrm{NaOH}$ or $\mathrm{NH}_{3} \mathrm{H}_{2} \mathrm{O}$ ), $\mathrm{Fe}^{3+}$ ions are converted to $\mathrm{FeOOH}$ through the intermediate $\mathrm{Fe}(\mathrm{OH})_{3}$ while $\mathrm{Fe}^{2+}$ ions to $\mathrm{Fe}(\mathrm{OH})_{2}$ (Eqs. 6 and 7), and the reaction between $\mathrm{FeOOH}$ and $\mathrm{Fe}(\mathrm{OH})_{2}$ gives the magnetite particles (Eq. 8) $[21 \bullet, 62]$ :

$$
\begin{aligned}
& \mathrm{Fe}^{3+}+3 \mathrm{OH}^{-} \rightarrow \mathrm{Fe}(\mathrm{OH})_{3} \rightarrow \mathrm{FeOOH}+\mathrm{H}_{2} \mathrm{O} \\
& \mathrm{Fe}^{2+}+2 \mathrm{OH}^{-} \rightarrow \mathrm{Fe}(\mathrm{OH})_{2} \\
& 2 \mathrm{FeOOH}+\mathrm{Fe}(\mathrm{OH})_{2} \rightarrow \mathrm{Fe}_{3} \mathrm{O}_{4}+2 \mathrm{H}_{2} \mathrm{O}
\end{aligned}
$$

Harris et al. [63] prepared a kind of triblock polymers stabilized magnetite nanoparticles. Stoichiometric aqueous solutions of $\mathrm{FeCl}_{2}$ and $\mathrm{FeCl}_{3}$ were condensed by reaction with $\mathrm{NH}_{4} \mathrm{OH}$ to form magnetite nanoparticles, and then the block copolymers were loaded onto the magnetite surfaces. TEM images showed a mean particle size of $8.8 \pm 2.7 \mathrm{~nm}$ and revealed formation of small aggregates. The main drawback of this method is the high cost of the block-copolymers and involvements of hazardous chemicals in the polymer synthesis. An et al. [21•] prepared stabilized magnetite nanoparticles using starch as a stabilizer and by pre-adding the stabilizer. They claimed that the particle size and stability can be tuned by adjusting the concentration of starch. They also introduced the concept of preparing "starch-bridged" or flocculated nanoparticles that could be obtained at relatively low concentrations of a stabilizer. The bridged nanoparticles retain the high adsorption capacity of nanoparticles, yet can be gravityseparated from water, thus are more suitable for water treatment. Fully stabilized nanoparticles $(26.6 \pm 4.8 \mathrm{~nm})$ were obtained at elevated starch concentrations, where starch serves as a steric stabilizer. Liang et al. [37] also prepared starchstabilized magnetite nanoparticles and found that the dynamic light scattering (DLS)-based hydrodynamic diameter was decreased from $\sim 4.4 \mu \mathrm{m}$, for non-stabilized particles, to 172 and $129 \mathrm{~nm}$, respectively, for particles stabilized with 0.04 and $0.1 \mathrm{wt} \%$ starch. Pan et al. [64] found CMC-stabilized magnetite appeared as discrete and well-dispersed particles.

Various synthetic magnetite particles have been tested for As removal from water [21, 65-68]. Yean et al. [67] found that the arsenic adsorption capacity was strongly related to the particle size. Mayo et al. [65] observed a 200 times increase of the sorption capacity for both $\mathrm{As}(\mathrm{III})$ and $\mathrm{As}(\mathrm{V})$ when the particle size was reduced from 300 to $12 \mathrm{~nm}$. The starchstabilized magnetite nanoparticles by An et al. [21 $\bullet$ ] offered an unprecedented Langmuir maximum adsorption capacity of $248 \mathrm{mg} / \mathrm{g}$ for $\mathrm{As}(\mathrm{V})$ at $\mathrm{pH} 5.0$, compared to $11.4 \mathrm{mg} / \mathrm{g}$ for the commercial aggregated magnetite. Liang et al. [37] compared 
the effectiveness of bare, starch-, and CMC-stabilized magnetite particles for $\mathrm{As}(\mathrm{V})$ removal. They observed the $\mathrm{As}(\mathrm{V})$ sorption capacity follows the sequence of starch-stabilized magnetite $>>C M C$-stabilized magnetite $>$ non-stabilized magnetite in the $\mathrm{pH}$ range of 3 to 11 . Although CMC gives a smaller particle size, it also induces a highly negative surface potential, which inhibits sorption of the target arsenic oxyanions; in contrast, the starch coating gives a nearly neutral surface potential, which is more favorable for interacting with arsenate. They also identified that inner-sphere complexation is the main binding mechanism. Liang et al. [68] also demonstrated the soil deliverability and effectiveness of starched-stabilized magnetite nanoparticles for in situ immobilization of $\mathrm{As}(\mathrm{V})$ in a model sandy loam soil. Batch and column experimental results revealed that water-leachable $\mathrm{As}(\mathrm{V})$ from the $\mathrm{As}(\mathrm{V})$-laden soil containing $31.45 \mathrm{mg} / \mathrm{kg}$ was reduced by $\sim 93 \%$ and the TCLP leachability by $>83 \%$ when the soil was treated with $34 \mathrm{PVs}$ of a $0.1 \mathrm{~g} \mathrm{Fe} / \mathrm{L}$ of the nanoparticle suspension.

\section{Stabilized Iron Phosphate Nanoparticles}

Phosphate compounds and related materials have been shown to be effective for immobilization of $\mathrm{Pb}, \mathrm{Cd}$, and $\mathrm{Cu}$ in contaminated soil and water [69-76]. Phosphate amendment induces the formation of secondary metal phosphate precipitates which usually possess fairly low solubility products [74], and thus are stable over a wide range of environmental conditions, resulting in lower leachability or bioavailability of the heavy metals. Iron phosphate nanoparticles are effective in heavy metal immobilization. Compared to solution phosphate, which has been used to immobilize metals, the nanoparticles offer the advantage of less phosphate leaching and longer lasting reactivity, as the nanoparticles delivered in soil serve as an immobile sink for capturing the target metals [77]. Liu and Zhao [78] developed a novel stabilized vivianite nanoparticle $(8.4 \pm 2.9 \mathrm{~nm})$ by reacting $\mathrm{Fe}^{2+}$ with phosphate according to the following stoichiometry in the presence of CMC as a stabilizer:

$3 \mathrm{Fe}^{2+}+2 \mathrm{PO}_{4}{ }^{3-}+8 \mathrm{H}_{2} \mathrm{O} \rightarrow \mathrm{Fe}_{3}\left(\mathrm{PO}_{4}\right)_{2} \cdot 8 \mathrm{H}_{2} \mathrm{O}$

In situ immobilization of $\mathrm{Pb}$ (II) in contaminated soils with phosphate-based amendments has elicited a great deal of attention [79-81]. Soluble phosphoric acid or phosphate salts can precipitate the metals, but are costly and can lead to secondary contamination problems due to excessive phosphate leaching. Phosphate rocks can reduce phosphate leaching but the effectiveness is hindered by the large size of the particles. Stabilized vivianite nanoparticles offer both good reactivity and controlled soil transportability (i.e., the particles are deliverable under pressure, yet hardly leachable once the delivering pressure is released). Liu and Zhao [78] developed and tested
CMC-stabilized iron phosphate to reduce leachability of lead in three model soils. Batch test results showed that the CMCstabilized nanoparticles effectively reduced the TCLP leachability of $\mathrm{Pb}$ (II) by $85-95 \%$, and the physiologically based extraction test (PBET) bioaccessibility by $31-47 \%$ when the soils were treated for 56 days at a nanoparticle dosage of 0.61 to $3.0 \mathrm{mg} / \mathrm{g}$ soil as $\mathrm{PO}_{4}{ }^{3-}$. In addition, they observed that the use of the nanoparticles resulted in $\sim 50 \%$ reduction in phosphate leaching compared to soluble phosphate. Liu and Zhao [78] also studied the in situ immobilization of $\mathrm{Cu}$ (II) in soils using same $\mathrm{CMC}$-stabilized iron phosphate nanoparticles and found that $\mathrm{Cu}$ leachability reduced by $63-87 \%$ when soils were treated with nanoparticles at $3.01 \mathrm{mg} / \mathrm{g}$ as $\mathrm{PO}_{4}{ }^{3-}$. Sequential extraction procedures also showed significant decrease in water-soluble/exchangeable $\mathrm{Cu}(\mathrm{II})$ and carbonate bound fractions, but increase in the residual fraction after the soils were amended with the nanoparticles, suggesting that the formation of copper phosphate minerals through precipitation and adsorption was the primary mechanism for $\mathrm{Cu}$ immobilization.

\section{Stabilized Fe-Mn Oxides Nanoparticles}

Binary metal oxides, such as Fe-Mn oxide, are commonly present in the environment [82]. They can offer high adsorption capacities for anions (e.g., As and Se oxyanions) compared to the single oxide minerals due to increased specific surface area, concurrent redox reactions, and/or anion exchange [83]. Typically, Fe-Mn binary oxide is synthesized per the following reactions [84]:

$$
\begin{aligned}
& 3 \mathrm{Fe}^{2+}+\mathrm{MnO}_{4}{ }^{-}+4 \mathrm{OH}^{-}+3 \mathrm{H}_{2} \mathrm{O} \rightarrow 3 \mathrm{Fe}(\mathrm{OH})_{3} \\
& +\mathrm{MnO}_{2}+\mathrm{H}^{+} \\
& 2 \mathrm{Fe}(\mathrm{OH})_{3} \rightarrow \mathrm{Fe}_{2} \mathrm{O}_{3}+3 \mathrm{H}_{2} \mathrm{O}
\end{aligned}
$$

To enhance the particle deliverability for in situ remediation, An and Zhao [22•] synthesized a new class of stabilized Fe-Mn binary oxide nanoparticles for As(III) removal from water and soil. Water-soluble starch and CMC were used as the stabilizers and fully stabilized amorphous nanoparticles were obtained. The hydrodynamic diameter of was $348 \pm 46$ and $247 \pm 9 \mathrm{~nm}$ for CMC $(0.16 \mathrm{wt} \%)$ and starch $(0.19 \mathrm{wt} \%)$ stabilized nanoparticles, respectively, based on DLS measurement. At $\mathrm{pH}$ 5.5, the Langmuir maximum adsorption capacity was $338 \mathrm{mg} / \mathrm{g}$ for $\mathrm{As}(\mathrm{III})$ and $272 \mathrm{mg} / \mathrm{g}$ for $\mathrm{As}(\mathrm{V})$, which was much higher than non-stabilized Fe-Mn materials reported by others $[85,86]$. Moreover, when applied for in situ treatment of an As-laden soil through lab-scale column tests, the CMCstabilized Fe-Mn nanoparticles reduced the water leachable As by $91-96 \%$ and the TCLP leachability by $94-98 \%$. Xie et al. [87] studied in situ removal and immobilization of metalloid Se(IV) in soil using the same CMC- and starch- 
stabilized Fe-Mn nanoparticles and found that $>90 \%$ of water leachable Se(IV) was transferred to the nanoparticle phase, and thereby immobilized as nanoparticles were retained in the downstream soil matrix. In addition, TCLP leachability and the California waste extraction test (WET) leachability of Se(IV) reduced by 76 and $71 \%$, respectively, with the nanoparticle treatment.

Overall, stabilized nanoparticles are more efficient for metal removal than non-stabilized counterparts and offer the advantage of soil deliverability. The treatment is more effective from water solutions than for soil due to kinetic limitation and inhibitive effects of soluble components from soil. Table 1 compares the effectiveness of representative non-stabilized and stabilized nanoparticles for metals removal.

\section{Fate and Transport of Stabilized Nanoparticles}

From the in situ remediation standpoint, the transport of the nanoparticles must satisfy the following two features: (a) the nanoparticles should be deliverable into the subsurface, i.e., they should be mobile under a certain injection pressure to ensure delivery into the targeted contaminant zones, and (b) the delivered nanoparticles should be virtually immobile under typical natural groundwater flow conditions, i.e., once the external injection pressure is released, the nanoparticles should remain immobile, or in a confined domain, providing prolonged contaminant immobilization capacity. Indeed, researches have indicated that stabilized nanoparticles can well satisfy these essential criteria.

\section{Transport Models}

Typically, transport of nanoparticles is modeled based on the classic filtration theory [90], which states that the deposition of colloids in porous media is attributed to three filtration mechanisms: (a) direct interaction of the particles with the media (interception), (b) sedimentation due to gravity, and (c) diffusion due to Brownian motion [90]. Under steady and saturated flow conditions, transport of nanoparticles through a homogeneous porous medium can be described by the convective-dispersive transport equation with a term accounting for the first-order particle deposition [91]:

$R \frac{\partial C}{\partial t}=D \frac{\partial^{2} C}{\partial z^{2}}-V \frac{\partial C}{\partial z}-k_{d} C$

where $C$ is the liquid phase nanoparticle concentration, $t$ is the elapsed time, $z$ is the travel distance, $D$ is the hydrodynamic dispersion coefficient for the nanoparticles, $V$ is the pore fluid velocity, $k_{d}$ is the removal rate coefficient, and $R$ is the retardation factor accounting for possible retardation effect associated with sorption of the nanoparticles, which is defined by:

$R=1+\frac{\rho_{b} K_{d}}{f}$

where $\rho_{b}$ is the bulk density of the media bed, $K_{d}$ is the distribution coefficient of the nanoparticles between the solid and aqueous phases, and $f$ is the porosity of the porous medium.Based on the filtration theory, the firstorder rate constant can be calculated by [91]:

$k_{d}=\frac{V}{L} \ln \left(C_{e} / C_{0}\right)$

where $L$ is the length of the porous medium bed and $C_{e}$ and $C_{0}$ are the steady-state effluent and influent concentrations of the nanoparticles, respectively.

The maximum travel distance (MTD), defined as the distance at which $99.9 \%$ of the particles is removed from the solution, is determined by:

$L_{\max }=-\frac{2}{3} \frac{d_{c}}{(1-f) \alpha \eta_{0}} \ln (0.01)$

where $d_{c}$ is the diameter of the spherical collector, $\eta_{0}$ is the single-collector contact efficiency, and $\alpha$ is the attachment efficiency for particle deposition, which reflects the chemical interactions between particles and matrix surfaces; $\alpha$ is defined by:

$\alpha=-\frac{2}{3} \frac{d_{c}}{(1-f) L \eta_{0}} \ln \left(C_{e} / C_{0}\right)$

Column experiments are commonly used to determine the attachment efficiency for a given set of hydrodynamic and physicochemical conditions [92, 93].

\section{Transport of Stabilized Nanoparticles}

To demonstrate soil deliverability of stabilized nanoparticles, 1-D column breakthrough tests are often carried out. Xiong et al. [4] investigated transport of CMC-stabilized FeS nanoparticles $(500 \mathrm{mg} / \mathrm{L} \mathrm{FeS}$ with $0.20 \mathrm{wt} \% \mathrm{CMC})$ through a clay loam sediment. They found that the nanoparticles transportable through the sediment and full breakthrough (100\%) occurred at $\sim 18$ PVs. Mass balance calculation revealed that $\sim 33 \%$ of the nanoparticles were retained in the sediment before the full breakthrough. Gong et al. [47•] also tested deliverability and transport of the $\mathrm{CMC}$-stabilized $\mathrm{FeS}$ nanoparticles $(500 \mathrm{mg} / \mathrm{L} \mathrm{FeS}$ with $0.05 \mathrm{wt} \% \mathrm{CMC}$ ) with two fieldcontaminated sediments. Under an external pressure of $4.7 \mathrm{psi} / \mathrm{m}$ bed, full breakthrough of the nanoparticles $\left(C / C_{0}=\right.$ 
Table 1 Removal of metals with various non-stabilized and stabilized particles

\begin{tabular}{|c|c|c|c|c|}
\hline Particles & Target metal & Removal efficiency & Reaction conditions & References \\
\hline Non-stabilized nZVI & $\mathrm{Cr}(\mathrm{VI})$ & $52 \%$ at $60 \mathrm{~min}$ & $\mathrm{Fe}^{0}$ dosage $=0.1 \mathrm{~g} / \mathrm{L}$, initial $\mathrm{Cr}(\mathrm{VI})=10 \mathrm{mg} / \mathrm{L}, \mathrm{pH}=5.5$ & [31] \\
\hline Stabilized nZVI & $\mathrm{Cr}(\mathrm{VI})$ & $94 \%$ at $60 \mathrm{~min}$ & $\mathrm{Fe}^{0}$ dosage $=0.1 \mathrm{~g} / \mathrm{L}, \mathrm{CMC}=0.5 \mathrm{~g} / \mathrm{L}$, initial $\mathrm{Cr}(\mathrm{VI})=10 \mathrm{mg} / \mathrm{L}, \mathrm{pH}=5.5$ & {$[31]$} \\
\hline Non-stabilized FeS & $\operatorname{Hg}(\mathrm{II})$ & $q_{\mathrm{e}}^{\mathrm{a}}=1700 \mathrm{mg} / \mathrm{g}$ & FeS dosage $=0.4 \mathrm{~g} / \mathrm{L}, \mathrm{pH}=5.6$ & {$[88]$} \\
\hline Stabilized FeS & $\operatorname{Hg}(\mathrm{II})$ & $Q_{\max }^{\mathrm{b}}=3449 \mathrm{mg} / \mathrm{g}$ & FeS dosage $=2.5 \mathrm{mg} / \mathrm{L}, \mathrm{CMC}$-to-FeS molar ratio $=0.0010, \mathrm{pH}=7$ & [89] \\
\hline Non-stabilized magnetite & $\mathrm{As}(\mathrm{V})$ & $Q_{\max }=26.8 \mathrm{mg} / \mathrm{g}$ & Magnetite dosage $=0.1 \mathrm{~g} / \mathrm{L}$ as $\mathrm{Fe}, \mathrm{pH}=6.8$ & {$[37]$} \\
\hline Stabilized magnetite & $\mathrm{As}(\mathrm{V})$ & $Q_{\max }=62.1 \mathrm{mg} / \mathrm{g}$ & Magnetite dosage $=0.1 \mathrm{~g} / \mathrm{L}$ as $\mathrm{Fe}, \operatorname{starch}=0.1 \mathrm{wt} \%, \mathrm{pH}=6.8$ & {$[37]$} \\
\hline Non-stabilized Fe-Mn & $\mathrm{As}(\mathrm{III})$ & $Q_{\max }=119 \mathrm{mg} / \mathrm{g}$ & $\mathrm{Fe}-\mathrm{Mn}$ dosage $=0.2 \mathrm{~g} / \mathrm{L}, \mathrm{pH}=5.0$ & {$[85]$} \\
\hline Stabilized iron Fe-Mn & $\mathrm{As}(\mathrm{III})$ & $Q_{\max }=338 \mathrm{mg} / \mathrm{g}$ & Fe-Mn dosage $=0.27 \mathrm{~g} / \mathrm{L}, \mathrm{CMC}=0.16 \mathrm{wt} \%, \mathrm{pH}=5.5$ & {$[22 \bullet]$} \\
\hline Non-stabilized Fe-Mn & $\operatorname{As}(\mathrm{V})$ & $Q_{\max }=70 \mathrm{mg} / \mathrm{g}$ & Fe-Mn dosage $=0.2 \mathrm{~g} / \mathrm{L}, \mathrm{pH}=5.0$ & {$[85]$} \\
\hline Stabilized iron Fe-Mn & $\mathrm{As}(\mathrm{V})$ & $Q_{\max }=372 \mathrm{mg} / \mathrm{g}$ & Fe-Mn dosage $=0.27 \mathrm{~g} / \mathrm{L}, \mathrm{CMC}=0.16 \mathrm{wt} \%, \mathrm{pH}=3.0$ & {$[22 \cdot]$} \\
\hline
\end{tabular}

${ }^{\text {a }}$ Equilibrium adsorption capacity

${ }^{\mathrm{b}}$ Langmuir maximum adsorption capacity

0.7-0.8) occurred at $\sim 9-12$ PVs for the two sediments, indicating good dispersibility of the nanoparticles. In all cases, non-stabilized FeS aggregates were not transportable (all particles were retained on the top layer of the sediment). An and Zhao [22 • ] observed that CMC-stabilized Fe-Mn binary oxide nanoparticles were transportable through a sandy soil and the breakthrough of the nanoparticles started almost simultaneously with the tracer $\mathrm{Br}^{-}$at $\sim 1 \mathrm{PV}$ and reached almost a nearly complete breakthrough $\left(C / C_{0}=0.9\right)$ at $\sim 4$ PVs. They also estimated that under specified injection pressure, the maximum travel distance of the nanoparticles is $1.11 \mathrm{~m}$, and the delivered nanoparticles would remain in the sediment when the external pressure is released.

He et al. [94] tested and modeled transport of CMCstabilized ZVI nanoparticles through various porous media (coarse glass bead, find glass bead, sand, and sandy soil). They not only demonstrated the soil deliverability but also showed that the filtration removal or the maximum travel distance of the nanoparticles was a function of the injection pressure or pore flow velocity. For instance, at a fixed attachment efficiency $(\alpha)$ of 0.0019 , the maximum travel distance increased from 5.3 to $10 \mathrm{~m}$ when the pore velocity increased from $2.0 \times 10^{-4}$ to $4.0 \times 10^{-4} \mathrm{~m} / \mathrm{s}$. They also showed that the delivered CMC-stabilized ZVI would remain within $\sim 16 \mathrm{~cm}$ at typical groundwater flow velocities (e.g., $0.1 \mathrm{~m} /$ day).

Saleh et al. [95] studied the mobility of surface-modified nZVI nanoparticles in water-saturated sand columns at different ionic strengths. The stabilized ZVI particles were prepared through a post-aggregation method by adsorbing the stabilizers onto the preformed particles. Both polyaspartate- and sodium dodecyl benzene sulfonate were found effective stabilizers at low ionic strengths. Triblock copolymer-modified ZVI particles showed the highest apparent negative zeta potential $(-50 \pm 1.2 \mathrm{mV})$ and the greatest mobility due to the electrosteric stabilization afforded by the triblock copolymer but not the other modifiers that provided primarily electrostatic stabilization. PAA was also found to enhance transport of nanoscale iron particles [96].

Transformations of stabilized nanoparticles may occur when injected into soils, especially for some nanoparticles with high reactivity or when exposed to reactive biogeochemical conditions. The reactions may alter size, morphology, and chemical compositions of the nanoparticles and thus change the transport characteristics. For example, Johnson et al. [97••] studied the field-scale transport and transformation of CMCstabilized ZVI during subsurface injection in a threedimensional model aquifer $(10 \times 10 \times 2.4 \mathrm{~m})$ containing layers of fine, medium, and coarse sand. While stabilized ZVI particles were able to transport over up to $2.5 \mathrm{~m}$ under veryaggressive flow conditions, total unoxidized ZVI particles transported only about $1 \mathrm{~m}$. The results suggested that the reactions of nZVI with oxidizing constituents of the groundwater including water, dissolved oxygen, and matrix material may have largely altered the particle size and transport behavior. However, little information is available on the fate and transformation of other stabilized nanoparticles (like FeS, $\mathrm{Fe}_{3}\left(\mathrm{PO}_{4}\right)_{2}, \mathrm{Fe}_{3} \mathrm{O}_{4}$, etc. $)$.

\section{Fate of Stabilized Nanoparticles After In Situ Remediation}

Very limited information is available pertaining to the environmental fate and transformation of stabilized nanoparticles. Reactive nanoparticles such as ZVI and FeS are expected to be oxidized iron (hydr)oxides, which can precipitate or more easily removed in the soil pores. The stabilizers, such as starch and $\mathrm{CMC}$, are biocompatible and are susceptible to biodegradation and hydrolysis, which can breakdown the polysugars in weeks. Depletion of the stabilizers from the nanoparticles enhances immobilization of the nanoparticles as well as the heavy metals sorbed thereon. Wang et al. [98] reported that 
freshly prepared CMC-stabilized ZVI nanoparticles are more likely to be taken up by plants than aged counterparts, and reaction with $\mathrm{Cr}(\mathrm{VI})$ may suppress plant uptake of the nanoparticles. Yet, our understanding of the environmental remains rudimentary.

\section{Toxicity of Stabilized Nanoparticles}

Researchers reported that the CMC-coating could reduce the cytotoxicity of ZVI nanoparticles toward bacteria Agrobacterium sp. PH-08, owing to reduced oxidative stress and less disruption of cell membrane integrity [99]. TEM images of the microstructure change of bacterial cells that were exposed to bare or CMC-stabilized ZVI indicated that bare ZVI-treated cells partially lost the outer boundary, indicating drastic membrane decomposition and severe damage; however, the membrane damage by CMC-stabilized ZVI was to a much less extent. A probable reason was CMC may act as a radical scavenger and compete with bacteria for oxidants. Moreover, the CMC-induced highly negative potential also created an unfavorable condition with interact with the negatively charged bacteria cells. Li et al. [100•] reported that polyelectrolyte coatings and natural organic matter (NOM) significantly decreased the toxicity of ZVI for Escherichia coli. They found that exposure to $100 \mathrm{mg} / \mathrm{L}$ of bare NZVI at an Fe concentration of $28 \%$ resulted in a 5.2-log inactivation for Escherichia coli after $60 \mathrm{~min}$, while only $0.2-\log$ inactivation for poly(styrene sulfonate), poly(aspartate), or NOM-stabilized $\mathrm{Fe}^{0}$. Coating of magnetic nanoparticles (MNPs) with biopolymers such as polysaccharides was also reported to lower toxicity of the nanoparticles for biomedical applications [101].

\section{Conclusions and Future Research Needs}

The uses of novel macromolecular stabilizers such as CMC and starch are able to facilitate soil delivery of nanoparticles for in situ remediation of metal-contaminated water and soil. In addition, the stabilized nanoparticles may offer greater reactivity or adsorption capacity due to much reduced particle size and elevated specific surface area, compared to non-stabilized particles. Furthermore, particle stabilization (e.g., using CMC as a stabilizer) may greatly reduce adverse effects of nanoparticles. However, it should be noted that the stabilizers may reduce the adsorption capacity for like-charged ions (e.g., CMC for arsenate) and detailed information is lacking on the toxicity, fate, and transformation of various stabilized nanoparticles.

The stabilized nanoparticles have shown promising for being directly delivered into the contaminated aquifers toward in situ immobilization of toxic metals in soil/sediment and water. Optimal stabilized nanoparticles may be prepared according to physico-chemical characteristics of individual metals such as the solubility product value between the metal ions and the nanoparticles and the ability to form surface complexation. Generally, stabilized nanoparticles were found less toxic than the non-stabilized counterparts. This review reveals the following knowledge gaps and further research needs:

(a) Although the stabilization technique (especially the use of $\mathrm{CMC}$ ) has greatly improved the soil deliverability of nanoparticles, the transport distance remains a bottle neck for effective application of the technology, especially for soil of low permeability. There is a need to further modify the particle stabilization technique and develop new stabilizers.

(b) While stabilizers enhance reactivity of the nanoparticles, the reactive lifetime of stabilized nanoparticles is reduced, especially for ZVI. In addition, side reactions may also consume the reactivity. To prolong reactivity, more advanced stabilization techniques are needed, alternatively composite bi-phasic materials with the more reactive phase as the core that is encapsulated by a less reactive shell.

(c) While lab-scale studies have revealed the promise of stabilized nanoparticles for in situ remediation of soil and groundwater, field data have been scare, especially for other nanoparticles than ZVI. Such data are critical to validate lab data and understand interactions between delivered nanoparticles and the affected biogeochemical conditions.

(d) More research is needed to determine the effects of environmental conditions on the fate, transport, and transformation of various stabilized nanoparticles.

(e) The effects of stabilized nanoparticles on biological activities should be investigated under environmentally relevant conditions.

(f) More mechanistically sounder transport model is needed for better predicting the transport and fate of stabilized nanoparticles in soil.

Acknowledgments This work was partially supported by the National Natural Science Foundation of China (Grant 41230638) and an Auburn University IGP Award.

Conflict of Interest On behalf of all authors, the corresponding author states that there is no conflict of interest.

\section{References}

Papers of particular interest, published recently, have been highlighted as:

- Of importance

•- Of major importance

1. Amin N, Hussain A, Alamzeb S, Begum S. Accumulation of heavy metals in edible parts of vegetables irrigated with waste water and their daily intake to adults and children, District Mardan. Pakistan Food Chem. 2013;136(3-4):1515-23. 
2. Singh RP, Agrawal M. Variations in heavy metal accumulation, growth and yield of rice plants grown at different sewage sludge amendment rates. Ecotoxicol Environ Saf. 2010;73(4):632-41.

3. Jeong HY, Klaue B, Blum JD, Hayes KF. Sorption of mercuric ion by synthetic nanocrystalline mackinawite (FeS). Environ Sci Technol. 2007;41(22):7699-705.

4. Xiong Z, He F, Zhao D, Barnett MO. Immobilization of mercury in sediment using stabilized iron sulfide nanoparticles. Water Res. 2009;43(20):5171-9.

5. Anirudhan TS, Divya L, Ramachandran M. Mercury(II) removal from aqueous solutions and wastewaters using a novel cation exchanger derived from coconut coir pith and its recovery. J Hazard Mater. 2008;157(2-3):620-7.

6. Kerin EJ, Gilmour CC, Roden E, Suzuki MT, Coates JD, Mason RP. Mercury methylation by dissimilatory iron-reducing bacteria. Appl Environ Microbiol. 2006;72(12):7919-21.

7. Zhang L, Planas D. Biotic and abiotic mercury methylation and demethylation in sediments. Bull Environ Contam Toxicol. 1994;52(5):691-8.

8. Bayramoğlu G, Arica MY. Kinetics of mercury ions removal from synthetic aqueous solutions using by novel magnetic p(GMAMMA-EGDMA) beads. J Hazard Mater. 2007;144(1-2):449-57.

9. Han B, Runnells T, Zimbron J, Wickramasinghe R. Arsenic removal from drinking water by flocculation and microfiltration. Desalination. 2002;145(1-3):293-8.

10. An B, Fu Z, Xiong Z, Zhao D, SenGupta AK. Synthesis and characterization of a new class of polymeric ligand exchangers for selective removal of arsenate from drinking water. React Funct Polym. 2010;70(8):497-507.

11. MacDonald JA, Kavanaugh MC. Restoring contaminated groundwater: an achievable goal? Environ Sci Technol. 1994;28(8): 362A-8A.

12. O'Loughlin EJ, Kelly SD, Cook RE, Csencsits R, Kemner KM. Reduction of uranium(VI) by mixed iron(II)/iron(III) hydroxide (green rust): formation of $\mathrm{UO}_{2}$ nanoparticles. Environ Sci Technol. 2003;37(4):721-7.

13. Wildung RE, McFadden KM, Garland TR. Technetium sources and behavior in the environment. J Environ Qual. 1979;8(2):156-61.

14. He F, Zhao D. Manipulating the size and dispersibility of zerovalent iron nanoparticles by use of carboxymethyl cellulose stabilizers. Environ Sci Technol. 2007;41(17):6216-21.

15. He F, Zhao D, Paul C. Field assessment of carboxymethyl cellulose stabilized iron nanoparticles for in situ destruction of chlorinated solvents in source zones. Water Res. 2010;44(7):2360-70.

16. Müller NC, Nowack B. Nano zero valent iron - the solution for water and soil remediation. Report of the ObservatoryNANO, 2010: 1-34

17.• Tratnyek PG, Salter-Blanc A, Nurmi J, Amonette JE, Liu J, Wang CM, Dohnalkova A, Baer DR. Reactivity of zerovalent metals in aquatic media: effects of organic surface coatings. Pacific Northwest National Laboratory (PNNL), Richland, WA (US), Environmental Molecular Sciences Laboratory (EMSL), 2011. This work summarizes the commonly particle stabilization techniques.

18. He F, Zhao D. Preparation and characterization of a new class of starch-stabilized bimetallic nanoparticles for degradation of chlorinated hydrocarbons in water. Environ Sci Technol. 2005;39(9): 3314-20.

19. He F, Zhao D, Liu J, Roberts CB. Stabilization of Fe-Pd nanoparticles with sodium carboxymethyl cellulose for enhanced transport and dechlorination of trichloroethylene in soil and groundwater. Ind Eng Chem Res. 2007;46(1):29-34.

20. $\mathrm{Xu}$ Y, Zhao D. Reductive immobilization of chromate in water and soil using stabilized iron nanoparticles. Water Res. 2007;41(10): 2101-8.

21. An B, Liang Q, Zhao D. Removal of arsenic(V) from spent ion exchange brine using a new class of starch-bridged magnetite nanoparticles. Water Res. 2011;45(5):1961-72. This work presents effects of starch on particle stability and adsorption capacity.

22. An B, Zhao D. Immobilization of As(III) in soil and groundwater using a new class of polysaccharide stabilized $\mathrm{Fe}-\mathrm{Mn}$ oxide nanoparticles. J Hazard Mater. 2012;211-212:332-41. This work presents details on the preparation, adsorption and transport of stabilized Fe-Mn binary oxide nanoparticles.

23. Han B, Zhang M, Zhao D, Feng Y. Degradation of aqueous and soil-sorbed estradiol using a new class of stabilized manganese oxide nanoparticles. Water Res. 2015;70:288-99.

24. Schlesinger HI, Brown HC, Finholt AE, Gilbreath JR, Hoekstra HR, Hyde EK. Sodium borohydride, its hydrolysis and its use as a reducing agent and in the generation of hydrogen 1. J Am Chem Soc. 1953;75(1):215-9.

25. Corrias A, Ennas G, Licheri G, Marongiu G, Paschina G. Amorphous metallic powders prepared by chemical reduction of metal ions with potassium borohydride in aqueous solution. Chem Mater. 1990;2(4):363-6.

26. Glavee GN, Klabunde KJ, Sorensen CM, Hadjipanayis GC. Chemistry of borohydride reduction of iron(II) and iron(III) ions in aqueous and nonaqueous media. Formation of nanoscale $\mathrm{Fe}$, $\mathrm{FeB}$, and $\mathrm{Fe}_{2} \mathrm{~B}$ powders. Inorg Chem. 1995;34(1):28-35.

27. Wang $\mathrm{CB}$, Zhang W. Synthesizing nanoscale iron particles for rapid and complete dechlorination of TCE and PCBs. Environ Sci Technol. 1997;31(7):2154-6.

28. Schrick B, Hydutsky BW, Blough JL, Mallouk TE. Delivery vehicles for zerovalent metal nanoparticles in soil and groundwater. Chem Mater. 2004;16(11):2187-93.

29. Hoch LB, Mack EJ, Hydutsky BW, Hershman JM, Skluzacek JM, Mallouk TE. Carbothermal synthesis of carbon-supported nanoscale zero-valent iron particles for the remediation of hexavalent chromium. Environ Sci Technol. 2008;42(7):2600-5.

30. Ponder SM, Darab JG, Mallouk TE. Remediation of $\mathrm{Cr}(\mathrm{VI})$ and $\mathrm{Pb}$ (II) aqueous solutions using supported, nanoscale zero-valent iron. Environ Sci Technol. 2000;34(12):2564-9.

31. Wang Q, Qian H, Yang Y, Zhang Z, Naman C, Xu X. Reduction of hexavalent chromium by carboxymethyl cellulose-stabilized zerovalent iron nanoparticles. J Contam Hydrol. 2010;114(1-4):35-42.

32. Liu HF, Qian TW, Zhao DY. Reductive immobilization of perrhenate in soil and groundwater using starch-stabilized ZVI nanoparticles. Chin Sci Bull. 2013;58(2):275-81.

33. Gu B, Liang L, Dickey MJ, Yin X, Dai S. Reductive precipitation of uranium(VI) by zero-valent iron. Environ Sci Technol. 1998;32(21):3366-73.

34. Fiedor JN, Bostick WD, Jarabek RJ, Farrell J. Understanding the mechanism of uranium removal from groundwater by zero-valent iron using X-ray photoelectron spectroscopy. Environ Sci Technol. 1998;32(10):1466-73.

35. Dickinson M, Scott TB. The application of zero-valent iron nanoparticles for the remediation of a uranium-contaminated waste effluent. J Hazard Mater. 2010;178(1-3):171-9.

36. Crane RA, Dickinson M, Popescu IC, Scott TB. Magnetite and zero-valent iron nanoparticles for the remediation of uranium contaminated environmental water. Water Res. 2011;45(9):2931-42.

37. Liang Q, Zhao D, Qian T, Freeland K, Feng Y. Effects of stabilizers and water chemistry on arsenate sorption by polysaccharidestabilized magnetite nanoparticles. Ind Eng Chem Res. 2012;51(5):2407-18.

38. Mosaferi M, Nemati S, Khataee A, Nasseri S, Hashemi A. Removal of arsenic (III, V) from aqueous solution by nanoscale zero-valent iron stabilized with starch and carboxymethyl cellulose. J Environ Health Sci Eng. 2014;12(1):74.

39. Kanel SR, Nepal D, Manning B, Choi H. Transport of surfacemodified iron nanoparticle in porous media and application to arsenic(III) remediation. J Nanopart Res. 2007;9(5):725-35. 
40. Brown JR, Bancroft GM, Fyfe WS, McLean RAN. Mercury removal from water by iron sulfide minerals. An electron spectroscopy for chemical analysis (ESCA) study. Environ Sci Technol. 1979;13(9):1142-4.

41. Morse JW, Arakaki T. Adsorption and coprecipitation of divalent metals with mackinawite (FeS). Geochim Cosmochim Acta. 1993;57(15):3635-40.

42. Chadha A, Sharma RK, Stinespring CD, Dadyburjor DB. Iron sulfide catalysts for coal liquefaction prepared using a micellar technique. Ind Eng Chem Res. 1996;35(9):2916-9.

43. Chin PP, Ding J, Yi JB, Liu BH. Synthesis of $\mathrm{FeS}_{2}$ and FeS nanoparticles by high-energy mechanical milling and mechanochemical processing. J Alloys Compd. 2005;390(1-2):255-60.

44. Paknikar KM, Nagpal V, Pethkar AV, Rajwade JM. Degradation of lindane from aqueous solutions using iron sulfide nanoparticles stabilized by biopolymers. Sci Technol Adv Mater. 2005;6(3-4):370-4.

45. Shi X, Sun K, Balogh LP, Baker JR. Synthesis, characterization, and manipulation of dendrimer-stabilized iron sulfide nanoparticles. Nanotechnology. 2006;17(18):4554-60.

46. Watson JHP, Croudace IW, Warwick PE, James PAB, Charnock JM, Ellwood DC. Adsorption of radioactive metals by strongly magnetic iron sulfide nanoparticles produced by sulfate-reducing bacteria. Sep Sci Technol. 2001;36(12):2571-607.

47. Gong Y, Liu Y, Xiong Z, Kaback D, Zhao D. Immobilization of mercury in field soil and sediment using carboxymethyl cellulose stabilized iron sulfide nanoparticles. Nanotechnology. 2012;23(29):294007. This work reports synthesis, applicaiton and transport of stabilized FeS nanoparticles.

48. Bower J, Savage KS, Weinman B, Barnett MO, Hamilton WP, Harper WF. Immobilization of mercury by pyrite $\left(\mathrm{FeS}_{2}\right)$. Environ Pollut. 2008;156(2):504-14.

49. Wang XB, Liu J, Zhao DL, Song XJ. Preparation of CMCstabilized FeS nanoparticles and their enhanced performance for Cr(VI) Removal. Adv Mater Res. 2011;287:96-9.

50. Shao D, Wang X, Li J, Huang Y, Ren X, Hou G, et al. Reductive immobilization of uranium by PAAM-FeS/ $\mathrm{Fe}_{3} \mathrm{O}_{4}$ magnetic composites. Environ Sci: Water Res Technol. 2015;1(2):169-76.

51. Özverdi A, Erdem M. $\mathrm{Cu}^{2+}, \mathrm{Cd}^{2+}$ and $\mathrm{Pb}^{2+}$ adsorption from aqueous solutions by pyrite and synthetic iron sulphide. J Hazard Mater. 2006;137(1):626-32.

52. Ito D, Miura K, Ichimura T, Ihara I, Watanabe T. Removal of As, $\mathrm{Cd}, \mathrm{Hg}$ and $\mathrm{Pb}$ ions from solution by adsorption with bacteriallyproduced magnetic iron sulfide particles using high gradient magnetic separation. IEEE T Appl Supercon. 2004;14(2):1551-3.

53. Erdem M, Ozverdi A. Kinetics and thermodynamics of Cd(II) adsorption onto pyrite and synthetic iron sulphide. Sep Purif Technol. 2006;51(3):240-6.

54. Hua B, Deng B. Reductive immobilization of uranium(VI) by amorphous iron sulfide. Environ Sci Technol. 2008;42(23): 8703-8.

55. Hyun SP, Davis JA, Sun K, Hayes KF. Uranium(VI) reduction by iron(II) monosulfide mackinawite. Environ Sci Technol. 2012;46(6):3369-76.

56. Lee JH, Zachara JM, Fredrickson JK, Heald SM, McKinley JP, Plymale AE, et al. Fe(II)-and sulfide-facilitated reduction of ${ }^{99} \mathrm{Tc}(\mathrm{VII}) \mathrm{O}_{4}{ }^{-}$in microbially reduced hyporheic zone sediments. Geochim Cosmochim Acta. 2014;136:247-64.

57. Huber DL. Synthesis, properties, and applications of iron nanoparticles. Small. 2005;1(5):482-501.

58. Kanel SR, Grenèche JM, Choi H. Arsenic(V) removal from groundwater using nano scale zero-valent iron as a colloidal reactive barrier material. Environ Sci Technol. 2006;40(6):2045-50.

59. Yavuz CT, Mayo JT, Yu WW, Prakash A, Falkner JC, Yean S, et al. Low-field magnetic separation of monodisperse $\mathrm{Fe}_{3} \mathrm{O}_{4}$ nanocrystals. Science. 2006;314(5801):964-7.
60. Dixit S, Hering JG. Comparison of $\operatorname{arsenic}(\mathrm{V})$ and $\operatorname{arsenic}(\mathrm{III})$ sorption onto iron oxide minerals: implications for arsenic mobility. Environ Sci Technol. 2003;37(18):4182-9.

61. Cornell RM, Schwertmann U. The iron oxides. Wiley-Blackwell; 2003.

62. Anderson PJ. On the ion adsorption properties of synthetic magnetite. Harwell, Berks, England: Gt. Brit. Atomic Energy Research Establishment; 1956.

63. Harris LA, Goff JD, Carmichael AY, Riffle JS, Harburn JJ, St. Pierre TG, et al. Magnetite nanoparticle dispersions stabilized with triblock copolymers. Chem Mater. 2003;15(6):1367-77.

64. Pan G, Li L, Zhao D, Chen H. Immobilization of non-point phosphorus using stabilized magnetite nanoparticles with enhanced transportability and reactivity in soils. Environ Pollut. 2010;158(1):35-40.

65. Mayo JT, Yavuz C, Yean S, Cong L, Shipley H, Yu W, et al. The effect of nanocrystalline magnetite size on arsenic removal. Sci Technol Adv Mater. 2007;8(1-2):71-5.

66. Gimenez J, Martinez M, Depablo J, Rovira M, Duro L. Arsenic sorption onto natural hematite, magnetite, and goethite. J Hazard Mater. 2007;141(3):575-80.

67. Yean S, Cong L, Yavuz CT, Mayo JT, Yu WW, Kan AT, et al. Effect of magnetite particle size on adsorption and desorption of arsenite and arsenate. J Mater Res. 2005;20(12):3255-64.

68. Liang Q, Zhao D. Immobilization of arsenate in a sandy loam soil using starch-stabilized magnetite nanoparticles. J Hazard Mater. 2014;271:16-23.

69. Yang J, Mosby DE, Casteel SW, Blanchar RW. Lead immobilization using phosphoric acid in a smelter-contaminated urban soil. Environ Sci Technol. 2001;35(17):3553-9.

70. Yang J, Mosby D. Field assessment of treatment efficacy by three methods of phosphoric acid application in lead-contaminated urban soil. Sci Total Environ. 2006;366(1):136-42.

71. Raicevic S, Kaludjerovic-Radoicic T, Zouboulis AI. In situ stabilization of toxic metals in polluted soils using phosphates: theoretical prediction and experimental verification. J Hazard Mater. 2005;117(1):41-53.

72. Wang Y, Chen TC, Yeh KJ, Shue MF. Stabilization of an elevated heavy metal contaminated site. J Hazard Mater. 2001;88(1):63-74.

73. Raicevic S, Wright J, Veljkovic V, Conca J. Theoretical stability assessment of uranyl phosphates and apatites: selection of amendments for in situ remediation of uranium. Sci Total Environ. 2006;355(1-3):13-24.

74. Lindsay, WL. Chemical equilibria in soils. John Wiley and Sons Ltd.; 1979.

75. Zhang WX. Nanoscale iron particles for environmental remediation: an overview. J Nanoparticle Res. 2003;5(3-4):323-32.

76. Cundy AB, Hopkinson L, Whitby RLD. Use of iron-based technologies in contaminated land and groundwater remediation: a review. Sci Total Environ. 2008;400(1-3):42-51.

77. Reynolds CS, Davies PS. Sources and bioavailability of phosphorus fractions in freshwaters: a British perspective. Biol Rev. 2001;76(1):27-64.

78. Liu R, Zhao D. Reducing leachability and bioaccessibility of lead in soils using a new class of stabilized iron phosphate nanoparticles. Water Res. 2007;41(12):2491-502.

79. Ma QY, Logan TJ, Traina SJ. Lead immobilization from aqueous solutions and contaminated soils using phosphate rocks. Environ Sci Technol. 1995;29(4):1118-26.

80. Zhang P, Ryan JA. Formation of pyromorphite in anglesitehydroxyapatite suspensions under varying $\mathrm{pH}$ conditions. Environ Sci Technol. 1998;32(21):3318-24.

81. Cao X, Ma LQ, Chen M, Singh SP, Harris WG. Impacts of phosphate amendments on lead biogeochemistry at a contaminated Site. Environ Sci Technol. 2002;36(24):5296-304. 
82. Szlachta M, Gerda V, Chubar N. Adsorption of arsenite and selenite using an inorganic ion exchanger based on $\mathrm{Fe}-\mathrm{Mn}$ hydrous oxide. J Colloid Interface Sci. 2012;365(1):213-21.

83. Goh KH, Lim TT, Dong Z. Application of layered double hydroxides for removal of oxyanions: a review. Water Res. 2008;42(6): 1343-68.

84. Wu K, Wang H, Liu R, Zhao X, Liu H, Qu J. Arsenic removal from a high-arsenic wastewater using in situ formed $\mathrm{Fe}-\mathrm{Mn}$ binary oxide combined with coagulation by poly-aluminum chloride. $\mathrm{J}$ Hazard Mater. 2011;185(2-3):990-5.

85. Zhang G, Qu J, Liu H, Liu R, Wu R. Preparation and evaluation of a novel $\mathrm{Fe}-\mathrm{Mn}$ binary oxide adsorbent for effective arsenite removal. Water Res. 2007;41(9):1921-8.

86. Chang F, Qu J, Liu H, Liu R, Zhao X. Fe-Mn binary oxide incorporated into diatomite as an adsorbent for arsenite removal: Preparation and evaluation. J Colloid Interface Sci. 2009;338(2): 353-8.

87. Xie W, Liang Q, Qian T, Zhao D. Immobilization of selenite in soil and groundwater using stabilized Fe-Mn binary oxide nanoparticles. Water Res. 2015;70:485-94.

88. Liu J, Valsaraj KT, Devai I, DeLaune RD. Immobilization of aqueous $\mathrm{Hg}(\mathrm{II})$ by mackinawite (FeS). J Hazard Mater. 2008;157(2-3):432-40.

89. Gong Y, Liu Y, Xiong Z, Zhao D. Immobilization of mercury by carboxymethyl cellulose stabilized iron sulfide nanoparticles: reaction mechanisms and effects of stabilizer and water chemistry. Environ Sci Technol. 2014;48(7):3986-94.

90. Yao KM, Habibian MT, O'Melia CR. Water and waste water filtration. Concepts and applications. Environ Sci Technol. 1971;5(11):1105-12.

91. Kretzschmar R, Barmettler K, Grolimund D, Yan Y, Borkovec M, Sticher H. Experimental determination of colloid deposition rates and collision efficiencies in natural porous media. Water Resour Res. 1997;33(5):1129-37.

92. Elimelech M, O'Melia CR. Kinetics of deposition of colloidal particles in porous media. Environ Sci Technol. 1990;24(10): $1528-36$.

93. Tufenkji N, Elimelech M. Correlation equation for predicting single-collector efficiency in physicochemical filtration in saturated porous media. Environ Sci Technol. 2004;38(2): 529-36.

94. He F, Zhang M, Qian T, Zhao D. Transport of carboxymethyl cellulose stabilized iron nanoparticles in porous media: column experiments and modeling. J Colloid Interface Sci. 2009;334(1): 96-102.

95. Saleh N, Kim HJ, Phenrat T, Matyjaszewski K, Tilton RD, Lowry GV. Ionic strength and composition affect the mobility of surface-modified $\mathrm{Fe}^{0}$ nanoparticles in watersaturated sand columns. Environ Sci Technol. 2008;42(9): 3349-55.

96. Hydutsky BW, Mack EJ, Beckerman BB, Skluzacek JM, Mallouk TE. Optimization of nano- and microiron transport through sand columns using polyelectrolyte mixtures. Environ Sci Technol. 2007;41(18):6418-24.

97.• Johnson RL, Nurmi JT, O’Brien Johnson GS, Fan D, O’Brien Johnson RL, Shi Z, et al. Field-scale transport and transformation of carboxymethylcellulose-stabilized nano zero-valent iron. Environ Sci Technol. 2013;47(3):1573-80. This work deeply studies the field-scale transport, transformation and fate of CMC-stabilized ZVI during subsurface injection in a model aquifer.

98. Wang Y, Fang Z, Kang Y, Tsang EP. Immobilization and phytotoxicity of chromium in contaminated soil remediated by CMCstabilized nZVI. J Hazard Mater. 2014;275:230-7.

99. Zhou L, Thanh TL, Gong J, Kim JH, Kim EJ, Chang YS. Carboxymethyl cellulose coating decreases toxicity and oxidizing capacity of nanoscale zerovalent iron. Chemosphere. 2014;104: 155-61.

100. Li Z, Greden K, Alvarez PJJ, Gregory KB, Lowry GV. Adsorbed polymer and NOM limits adhesion and toxicity of nano scale zerovalent iron to E. coli. Environ Sci Technol. 2010;44(9):3462-7. This work gives evidence of lower biotoxicity of stabilized ZVI compared to non-stabilized nanoparticles.

101. Dias AMGC, Hussain A, Marcos AS, Roque ACA. A biotechnological perspective on the application of iron oxide magnetic colloids modified with polysaccharides. Biotechnol Adv. 2011;29(1): $142-55$. 